\title{
Variability Analysis for Various Quantitative Traits in Maize (Zea mays L.) Hybrids
}

\author{
B. Manjunatha*, B. Niranjana Kumara, H.G. Sannathimmappa and A.M. Maruthesha
}

Agricultural and Horticultural Research Station, Kathalagere

University of Agricultural and Horticultural Sciences, Shivamogga-577219, India

*Corresponding author

\section{A B S T R A C T}

The experiment was conducted at Agricultural and Horticultural Research Station, Kathal agere during kharif 2018. Estimation of variability parameters like environmental variability, Genotypic variability, Genotypic coefficient of variability, Phenotypic variability, Phenotypic Coefficient of Variability, Heritability $\left(h^{2}\right)$, Genetic advancement at $5 \%$, Genetic advancement as $\%$ of mean 5\% and General mean. In the present study twenty seven diverse hybrids were grown in RCBD design with three replications during Kharif 2018 to study the genetic parameters viz. ANOVA, GCV, PCV, h2 and Genetic Advance (GA). The results indicates that ANOVA for all the characters viz. cob weight, shelling $\%$, moisture $\%$, initial plants and, final plant stand, cob count, days to $50 \%$ pollen shed, days to $50 \%$ silking, days to $70 \%$ dry husk, plant height, ear height are highly significant while grain yield showed significant values. The high GCV and PCV values were observed for grain yield, cob weight while moderate GCV and PCV values were shown by moisture \%, days to $70 \%$ dry husk and cob count. High heritability coupled with high expected genetic advance in percent of mean was observed for grain yield, cob count, days to $70 \%$ dry husk, plant height and ear height. Conclusively PCV was higher GCV indicates that environmental role in the expression of these traits.

\section{Introduction}

Maize (Zea mays L.) is the third most important cereal crop after rice and wheat. Maize has myriad of uses in food, feed and industrial segment. Globally 67 per cent of maize is used for livestock feed, 25 per cent for human consumption, $14 \%$ for starch products, $1 \%$ each for beverages and seed and rest for industrial purposes. Genetic EEC 2015 - 278 variability is of greatest interest to the plant breeder as it plays a vital role in framing successful breeding programme. Heritability of a metric character is a parameter of particular significance as it measures the degree of resemblance between the parents and off-springs. The knowledge of heritability enables the plant breeder to decide the course of selection procedure to be followed under a given situation ( $\mathrm{Li}$ and Yang, 1985). Genetic advance aids in exercising the necessary selection pressure. Keeping in view 
the importance of these aspects a study was conducted to know variability, heritability and genetic advance in twenty seven in breds of maize which will help to ascertain the real potential value of the genotypes.

\section{Materials and Methods}

The experimental materials consisted of twenty seven inbred lines of maize obtained from All India Coordinated maize research centre, Regional station, Hyderabad. Twenty seven genotypes were sown during kharif, 2018 in Randomized Block Design with three replications. Each entry was sown as four rows of 4 meter length with row-to-row and plant-to-plant distance of $75 \mathrm{~cm}$ and $30 \mathrm{~cm}$ respectively. All the agronomic practices along with prophylactic plant protection measures were followed so as to raise a good crop. Observations were recorded on five randomly selected plants for Plant height (cm), Plant stand, Moisture (Per cent), Ear height $(\mathrm{Cm})$, Cob Weight. (Kg), Number of Cobs. However, observations for the characters namely days to 50 per cent tasseling, days to 50percent silking, days to maturity were recorded on plot basis. Analysis of variance was computed based on Randomized Block Design for each of the character separately as per standard statistical procedure given by (Panse and Sukhatme, 1978). Heritability $\left(\mathrm{h}^{2}\right)$ in the broad sense was calculated according to the formula given by (Allard, 1960) for all characters. Phenotypic and genotypic coefficients of variation (PCV and GCV) were computed according to(Burton,1952). For statistical analysis, Windostat Version 9.1 software package was used.

\section{Results and Discussion}

Analysis of variance for the experiment involving a set of 27 hybrid lines of maize for six quantitative traits revealed highly significant mean sum of squares for all the characters indicating greater diversity among the genotypes. The results of significant mean sum of squares due to genotypes for all the traits studied were reported by (Manjunatha et al., 2018, Rafiq et al., 2010; Reddy et al., 2013; Nagabhushan et al., 2011; Suresh et al., 2012). The results pertaining to genetic parameters viz., phenotypic coefficient of variation (PCV), genotypic coefficient of variation (GCV), broad sense heritability (h) and genetic advance as percent of mean(GAM) for all the six characters are furnished in Table 1. The Highest magnitude of both PCV (12.87\%) and GCV (42.5\%) were observed forcob weight followed by ear height $(4.3 \%-12.63 \%)$ suggesting that these characters were under the influence of genetic control. Similar reports were earlier given by (Akbar et al., 2008; Reddy et al., 2013) for cob weight and ear height. The characters plant height (9.3\%-7.33\%), plant stand (3.5\%7.08)were recorded for moderate magnitudes of both PCV and GCV, respectively. Similar results were reported by (Krishnam Raju, 2001) for days to $50 \%$ tasseling indicating the predominance of non-additive gene action. The phenotypic coefficient of variation was higher than genotypic coefficient of variation (GCV) for all the characters under study but the GCV was greater than the variation produced by the environment for all the characters. The results are in agreement with the findings of (Srivas and Singh, 2004; Abirami et al., 2005; Mustafa et al., 2014).

Heritability estimates were high for all the traits under study except cob weight which recorded moderate estimate of heritability. This suggested the greater effectiveness of selection and improvement to be expected for these characters in future breeding programme as the genetic variance is mostly due to the additive gene action. The results are in consonance with the reports given by (Natraj et al., 2014) for cob weight, ear height, plant height. 
Table.1 Variability parameters for various quantitative traits of maize inbreeds

\begin{tabular}{|l|c|c|c|c|c|c|}
\hline \multicolumn{1}{|c|}{ Variability parameters } & $\begin{array}{c}\text { Plant } \\
\text { height(cm) }\end{array}$ & $\begin{array}{c}\text { Plant } \\
\text { stand }\end{array}$ & $\begin{array}{c}\text { Moisture } \\
\text { (Per } \\
\text { cent) }\end{array}$ & $\begin{array}{c}\text { Ear } \\
\text { height } \\
(\mathbf{C m})\end{array}$ & $\begin{array}{c}\text { Cob } \\
\text { Weight } \\
(\mathbf{K g})\end{array}$ & $\begin{array}{c}\text { Cobs } \\
\text { (Number) }\end{array}$ \\
\hline Environmental variability & 383.23 & 16.5 & 0.87 & 164.6 & 53953.9 & 16.53 \\
\hline Genotypic variability & 6.11 & 5.34 & 0.138 & 22.23 & 49.51 & 5.35 \\
\hline GCV & 0.93 & 3.5 & 2.055 & 4.36 & 12.87 & 3.50 \\
\hline Phenotypic variability & 377.12 & 21.8 & 0.73 & 186.9 & 54003.4 & 21.88 \\
\hline PCV & 7.33 & 7.08 & 4.74 & 12.63 & 425.15 & 7.08 \\
\hline Heritability & 42.00 & 44.00 & 48.00 & 61.00 & 51.00 & 25.00 \\
\hline $\begin{array}{l}\text { Genetic advancement } \\
\text { @5\% }\end{array}$ & 0.65 & 2.35 & 0.33 & 3.35 & 0.439 & 2.35 \\
\hline $\begin{array}{l}\text { Genetic advancement as \% } \\
\text { of mean 5\% }\end{array}$ & 0.24 & 3.56 & 1.83 & 4.3 & 0.562 & 4.57 \\
\hline General mean & 264.9 & 66.06 & 18.07 & 108.23 & 54.66 & 66.06 \\
\hline
\end{tabular}

Higher genetic advance was found for plant height $(65.00 \%)$ followed by ear height (61.86\%),plant height $(6.5 \%)$, cob weight (43.9\%), number of cobs per plant $(23.5 \%)$ and plant stand $(23.5 \%)$. Similar results for high genetic advance for grain yield per plant were earlier reported by (Arun Kumar Singh et al. 2018; Suresh et al., 2012; Kanagarasu et al., 2013; Bekele et al., 2014). High heritability coupled with high genetic advance was observed for grain yield per plant, ear height and plant height and ear length. It indicates the role of additive gene action in controlling the traits; hence pedigree method of breeding will be a rewarding one to improve the traits under investigation. Similar results were reported by (Kabdal et al., 2003) for grain yield, plant height, ear height and ear length. For grain yield per plant and number of kernelsper row (Hepziba et al., 2013).

In conclusion, high estimates of PCV and GCV were recorded for grain yield per plant and ear height which provides considerable variability and offers scope for genetic improvement through selection. Further high heritability coupled with high genetic advance were observed for grain yield per plant, ear height, plant height, number of kernels per row, 100 - seed weight and ear length Indicate the role of additive gene action in controlling the traits, hence pedigree method of breeding will be a rewarding one to improve the traits under investigation.

\section{References}

Abirami, S., Vanniarajan, C. and Armugachamy, S. 2005. Genetic variability studies in maize (Zea mays L.) germplasm. Plant Archives. 5 (1): 105-108.

Akbar, M., Shakoor, S., Hussain, A. and Sarwar, M. 2008.Evaluation of maize 3-way crosses through genetic variability, broad sense heritability, characters association and path analysis. Journal of Agricultural Research. 46 (1): $39-45$.

Allard, R.W. 1960. Principles of Plant Breeding. John Wiley and Sons Inc., New York, USA. pp. 485.

Arun Kumar Singh, S.P. Mishra and Roshan Parihar. 2018, Studies on Genetic Variability Parameters on Grain Yield and Its Yield Attributing Traits in Maize (Zea mays L.), Int.J.Curr.Microbiol.App.Sci, 7(9): 1261-1266

Bekele, T. A. and Rao, N. 2014. Estimates of heritability, genetic advance and correlation 
study for yield and it's attributes in maize (Zea Mays L.). Journal of Plant Sciences. 2 (1): 1-4.

Burton, G.W. 1952. Quantitative inheritance in grasses. Proceedings of sixth International Grassland Congress. 1: 227-281.

Hepziba, S.J., Geetha, K. and Ibrahim, S.M. 2013. Evaluation of genetic diversity, variability, character association and path analysis in diverse inbreds of maize (Zea mays L.). Electronic Journal of Plant Breeding. 4(1): 1067-1072.

Kabdal, M.K., Verma, S.S., Ahmad, N. and Panwar, U.B.S. 2003. Genetic variability and correlation studies of yield and its attributing characters in maize (Zea mays L.). Agricultural Science Digest. 23 (2): 137-139.

Kanagarasu, S., Nallathambi, G., Kannan, S. and Ganesan, K.N. 2013. Genetic variability and association analysis for yield and its components in single cross hybrids of maize (Zea mays L.). Electronic Journal of Plant Breeding.4 (4): 1319-1324.

Krishnam Raju, K. 2001. Variability studies for protein content and grain yield in maize (Zea mays L.) genotypes. M. Sc. Thesis, Acharya N. G. Ranga Agricultural University, Rajendranagar, Hyderabad.

Li, C.M. and Yang, K.C. 1985. Studies on inheritance of quantitative characters for plant type in some inbred lines of maize. Scientia Agriculture Sinical. 9: 28-36.

Manjunatha. B, Niranjana Kumara. B and G.B. Jagadeesh, 2019. Performance Evaluation of Maize Hybrids (Zea mays L.). Int.J.Curr.Microbiol.App.Sci (2018) 7(11): 1198-1203.

Mustafa, H.S.B., Aslam, M., Hasan, E., Hussain, F. and Farooq, J. 2014. Genetic variability and path coefficient in maize (Zea mays L.) genotypes. The Journal of Agricultural
Sciences. 9: 37-43.

Nagabhushan, N.M., Chandrashekhar, H., Shashibhaskar, M.S. and Prahalada, G.D. 2011. Genetic variability and correlation studies for yield and related characters in single cross hybrids of maize (Zea mays L.). Current Biotica. 5(2): 157-163.

Nataraj, V., Shah, J.P. and Vandana, D. 2014. Estimates of variability, heritability and genetic advance in certain inbreeds of maize (Zea mays L.).International Journal of Applied Biology and Pharmaceutical Biology. 5(1): 205-208.

Panse, V.G. and Sukhatme, P.V. 1978. Statistical methods for Agricultural workers. Indian Council of Agricultural Research Publications, New Delhi. 235-246.

Rafiq, M., Rafique, M., Hussain, A. and Altaf, M. 2010. Studies on heritability, correlation and path analysis in maize (Zea mays L.). Journal of Agricultural Research. 48 (1): 35-38.

Reddy, V.R., Jabeen, F., Sudarshan, M.R. and Rao, A.S.2013. Studies on genetic variability, heritability, correlation and path analysis in maize (Zea mays L.) over locations. International Journal of Applied Biology and Pharmaceutical Technology. 4 (1): 195-199.

Srivas, S.K. and Singh, U.P. 2004. Genetic variability, character association and path analysis of yield and its component traits in forage maize (Zea mays L.). Range Management and Agro forestry. 25(2): 149153.

Suresh, H., Sasidharan, N., Chakraborty, S., Patel, J.N., Trivedi, R., Panwar, B.S. and Ashish Vala. 2012. Genetic analysis and character association studies for yield and different phenotypic characters in maize (Zea mays L.) International Journal of Plant Sciences. 7 (2): 341-350.

\section{How to cite this article:}

Manjunatha, B., B. Niranjana Kumara, H.G. Sannathimmappa and Maruthesha, A.M. 2019. Variability Analysis for Various Quantitative Traits in Maize (Zea mays L.) Hybrids. Int.J.Curr.Microbiol.App.Sci. 8(09): 365-368. doi: https://doi.org/10.20546/ijcmas.2019.809.043 